\title{
ANALISIS KONSTRUK PENGUKURAN PENGHARGAAN KENDIRI (SATU PERBANDINGAN ANTARA KONSTRUK BARAT DAN ISLAM)
}

\author{
KHAIRIL ANWAR \\ Email : eying74@yahoo.com \\ Universitas Islam Negeri Sultan Syarif Kasim Riau \\ Program Pasca Sarjana
}

\begin{abstract}
Abstrak
The purpose of this paper is to discuss the results of a measurement comparative between islamic self esteem constructs and Western construct. Self-esteem scale were used for the measurement of constructs sourced from western civilization is one of the most widely measurement tool used in the study of psychology local in Malaysia. The study involved a sample of 490 people consisting of teenagers aged between 15 and 21 years of rehabilitation centers peninsular Malaysia. Using content analysis approach and statistical approach, self-esteem measurement tool has been compared by measuring the psychosocial Islam, which constructs stem from a civilization that feels Qur'an and Sunnah. Through content analysis found that the items contained in the self-respect is closer to the concept of 'ujub (pride) which is very contrary to Islamic principles. While the approach berstatistik- although not signifi- found self-esteem measurement showed a negative direction index $(r=-.052)$ when correlated with measurements of psycho-social Islam. This way the higher meaning of the psycho-social self-esteem lowers the level of an individual. In terms of type and level of misconduct, that the higher levels of delinquency was also a tendency towards mean higher self-esteem. Cons with psycho-social measurement tool Islam, the higher levels of adolescent misbehavior is also a tendency towards psycho-social min lower. The findings are expected to be a psychological assessment movement among Muslims Islam sayugyanya should approach Islam.
\end{abstract}

Key word: Penghargaan Kendiri, Konstruk Barat, Islam

\section{Pengenalan}

Dalam perspektif sejarah dapat dikatakan IIrnu psikologi atau ilmu jiwa berpunca daripada pemikiran Yunani sejak abad ke empat sebelurn Masihi lagi (Wilcox 1995 :6; Absar 1992: 16 Dalam Mosata kamal, 2009). Dalam tradisi berfiikir ahli falsafah Yunani menekankan bahawa manusia terdiri dari jasad dan minda yang kedua-duanya amat berbeza di antara satu sarna lain. Pemikiran ini disambung oleh Rene Descartes (15641642) filasuf Perancis yang dianggap sebagai Bapa Falsafah Moden dengan faham Dualisme-nya. Selain dualisme descartes terdapat pula Idealisme, salah satu daripada cabang aliran Monisme, seperti yang dipopularkan 
oleh George Berkeley (1685-1753) yang menyatakan bahawa manusia ini hanya mindanya sahaja. Manakala aliran Monisme yang hanya mengutamakan jasad manusia sahaja dikenali sebagai Materialisme atau Fizikalisme. Dalam aliran ini, minda difahami sebagai tidak lebih daripada hasil at au proses akibat (epi-phenomena) daripada aktiviti otak manusia itu sendiri. Apabila manusia 'berfikir', saraf-saraf serebrum dalarn otak manusia melakukan aktiviti pemikiran, dan inilah yang dikenali sebagai 'minda'. Aliran ini menolak aliran yang menyatakan bahawa minda berbeza daripada badan yang terdiri daripada elemen alam idea seperti yang diutarakan oleh aliran Dualisme. Bahkan minda pada pandangan mereka hanya entiti alam benda yang lebih halus, seni dan sukar diamati dengan mata kasar. Dengan kata lain, apa yang dikatakan sebagai minda hanyalah proses dan hasil daripada aktiviti otak manusia itu sendiri yang bersifat benda halus atau konseptual. Aliran ini nampaknya menolak sama sekali sebarang elemen rohani atau roh dalam diri manusia. Manusia bagi mereka hanyalah jasadnya dan tidak lebih daripada itu. Pandangan seumpama ini lebih dikenali sebagai teori identiti. Antara penulisan yang menyokong pandangan ini ialah penulisan Hugh Elliot (1881-1930) bertajuk 'Modern Science and Materialism' (Kessler 1992: 438-445 Dalam Mosata kamal, 2009).

Dari konsep asas ontologi manusia yang diutarakan oleh aliranaliran tersebut di atas, wujudlah modelmodel psikologi moden yang lebih khusus dan terperinci dalam mengkaji manusia dan tingkah lakunya. Model model ini berkembang dengan pesatnya hingga terciptanya 'psikologi Barat' yang mengkhususkan penelitian kepada hanya tingkah laku dan kognitif manusia dengan menggunakan metod saintifik. Oleh kerana metod kajian model-model ini hanya terbatas kepada kajian kuantitatif, eksperimen di makmal, dan bersifat posteriori yang berlandaskan lima deria, maka tujuan penelitian mereka tentang manusia hanya untuk menghurai, meramal, mengawal dan memantau mana-mana tingkah laku manusia yang boleh dilihat dan diukur secara kuantitatif. Antara model-model utama psikologi moden (Wilcox 1995; Alawi 1992) ialah model mekanika berasaskan aliran Behaviourisme atau psikologi eksperimental yang diwakili oleh Wilhelm Wundt (1833-1920), Wolfgang Kohler (1887 -1967), John B. Watson (1878-1958). Dalam model ini, manusia sepertijuga haiwan yang lain di dunia ini, adalah organisme yang boleh dibentuk dan diubahsuai kendirinya setelah tingkah lakunya difaharni, diramal dan dikawal melalui kajian eksperimen (Ansari 1992:87-97; Wilcox 1995 Dalam Mosata kamal, 2009).

\section{Permasalahan}

Prinsip utama Ilmu psikologi secara hakikatnya adalah memiliki tujuan yang sama dengan kajian bidang ilmu lainnya. Dalam arti yang sesungguhnya semua ilmu berprinsip dan memiliki hala nilai untuk lebih memahami arti manusia yang sebenarnya, yang pada akhirnya ingin mewujudkan manusia ideal yang sejahtera. Namun suatu stigma akan muncul apabila psikologi ini "dipaksakan" sebagai ilmu yang memiliki nilai-nilai universal untuk dijadikan asas memahami dan memberikan suatu perlakuan pada sikap dan tingkah laku manusia. 
Khairil Anwar; Analisis Konstruk Pengukuran Penghargaan Kendiri (Satu Perbandingan antara Konstruk Barat dan Islam)

Sesebuah masyarakat akan bersikap dan bertingkahlaku mengikut sosial budayanya tersendiri. Sebagai contoh, isu-isu dalam penggunaan pengukuran psikologi barat untuk mengukur fenomena masyarakta muslim hanya dibertakan pada persoalan konsep reliabiliti dan validiti sahaja. Dalam arti lain, reliabiliti dan validiti lebih difokuskan untuk mengubahsuai itemitem pengukuran agar lebih dapat difahami oleh responden dalam penyelidikan. Padahal yang paling penting untuk dikaji adalah sejauhmana kesesuaian konstruk pengukuran dimaksud dengan budaya masayarakat dari responden dalam penyelidikan. Bagaimanapun juga hakikat pembinaan pengukuran psikologi tidak terlepas dari konsep-konsep yang digunakan dalam psikologi. Sebagaimana psikologi barat, konsepnya adalah berakar dari humanis-materialisme dan behaviorismetrialisme Berbeza dengan masyarakat Islam, berbudaya berasaskan al-Qur'an dan hadis, yang secara sentral berkonsepkan kepada taqwa. Ketakwaan adalah sebagai wujud dari kesedaran keTuhanan (Godconssciousness) sebagai omnipresent atau menghadirkan Tuhan dalam hidup manusia yang diwujudkan dengan hidup berpandukan wahyu dari Yang Maha Kuasa.

Kesederan ketuhanan dalam Islam adalah sangat bertolak belakang dengan asas psikologi barat yang berasaskan dari pemikirian manusia itu sendiri, seperti aliran psikoanalitik, behavioristik dan humanistik. Hal ini adalah berpunca dari apa yang dikatakan oleh al Attas (Lih. DIm Wan Mohd. Nor Wan Daud, 1991) roh dan peribadi kebudayaan dan tamaddun barat moden berteraskan oleh tiga factor utama:

1. konsep dualisme yang menguasai pandangan mereka tentang reality dan kebenaran. Konsep dualisme ini juga mewarnai berbagai-bagai aspek pemikiran dan kehidupan. Contohnya dualisme antara akal dan jasad, dan pemisahan antara kaedah rasionalisme dengan empirisme

2. Ajaran humanisme, iaitu jelmaan ideologi sekularisme yang memusatkan penilaian segalagalanya kepada fikiran manusia.

3. Konsep tragedi yang menysup dalam setiap arena kehidupan baik falsafah, agama atau kesenian. Konsep ini mencerminkan jiwa tidak beriman kerana kecewa dengan agama. Konsep tragedi ini mengakibatkan mereka asyik berpandu kepada keraguan, dan dalam proses ini falsafah telah diiktiraf sebagai alat utama menuntut kebenaran yang tiada tercapai.

Menurut al Hashimi (1989) Islam berpendapat pengajian berkenaan jiwa manusia merupakan aktiviti-aktiviti saintifik yang berguna dan patut digalakkkan seperti ilmu pengetahuan yang lain. Tidak dapat dinafikan lagi bahwa Qur'an bukanlah buku teori psikologi Sains, geografi atau kosmos. Qur'an merupakan sebuah buku yang membimbing, mendedahkan rahsiarahsia berkenaan jiwa dan alam kepada manusia supaya manusia dapat memahami dan menggunakan alam ini untuk beribadat kepada Allah SWT. Qur'an menyatakan potansi-potensi dan kelemahan-kelemahan jiwa manusia, dan mengemukakan panduan-panduan dan penyelewengan penyelewengan. 
Oleh itu perkataan (nafs, diri dan jiwa) di ulang sebanyak lebih dari 300 kali di dalam Qur'an pada berbagai konteks.

Sebagaimana permasalahan utama tulisan ini untuk mengungkapkan perbandingan konstruk barat dan Islam, maka telah diambil satu pengukuran psikologi barat iaitu pengukuran penghargaan kendiri, yang dibina oleh M. Rosernberg (1965) dan kemudia alat ini diuji secara statistik hubungannnya dengan alat pengukuran psiko-sosial Islam yang dibina berdasarkan konsep Qur'an dan Hadis.

Dalam memandang konsep dan filsafat tentang manusia, maka tak lepas dari pandangan Islam sendiri tentang manusia. Dalam Islam, manusia memang makhluk yang memiliki dimensi-dimensi yang kompleks. Manusia dimanapun dan beragama apapun pasti tersusun dari jasad dan ruh. Jasad diertikan sebagai tubuh fisik, dan ruh sebagai kekuatan yang berasal dari Allah yang ditiupkan ke jasad manusia saat berusia 120 hari.

Tulisan ini tidak sedikitpun bermaksud menyebelahi keutamaan antara mind dan body, tapi lebih jauh adalah membicarakan muatan-muatan prinsip yang akan mengisi kesadaran dan hubungannya dengan mind dan body. Pengisian prinsip-prinsip hidup yang benar adalah membicarakan kualiti tentang manusia. Pembicaraan yang terlalu mendalam dalam aspek mind dan body secara saintifik empirical, tanpa membicarakan muatanmuatan prinsip yang mengisinya, pada dasarnya akan terus menggiring pembicaraan atas manusia dalam sudut yang materialistic.

Dalam konteks Islam mind dan body merupakan fitrah yang semula jadi yang sedia ada pada setiap manusia yang normal. Namun dalam Islam mind dan body masih bersifat materialistic tanpa ada nilai tertentu, sebelum mind dan body dihubungkan dengan ruh. Konsep ruh dalam Islam bukanlah konsep kehidupan, ruh adalah konsep kesedaran. Dalam alqur'an dikatakan ada dua kesadaran yang tanamkan Allah ke dalam ruh manusia iaitu fujur (kejahatan) dan taqwa (kebaikan). Tanpa bermaksud mendialogkan pertentangan anatara rasionalisma yang diwakili oleh pemikiran plato dengan empirisma yang diwakili oleh aristotel, jauh sebelum kematangan proses berfikir terjadi, manusia telah memiliki konsep kebenaran dan kesalahan. Konsep salah benar akan berkembang dengan adanya sentuhan antara kesadaran yang sedia ada dengan persekitaran. Pendek kata, yang menghubungkan kesadaran (baca; ruh) dengan persekitaran adalah mind dan body.

Dengan demikian, seandainya dilakukan penyederhanaan konsep maka dapat dikatakan Ruh (kesadaran) sebagai potensi, manakala alam perasekitaran dan agama adalah kualiti tertentu, dan selanjut mind dan body dapat dianggap sebagai alat penghubung antara ruh dan persekitaran.

Pada prinsipnya pembicaraan yang terpenting adalah terletak pada permaslahan ruh dan persekitaran, kerana kedua konsep inilah yang akan mempengaruhi mind dan body seseorang individu. Menstimulasi ruh dengan pendekatan persekitaran yang selamat akan berimpak kepada symbolsimbol mind dan body yang selamat. Sosiokultur keagamaan yang benar akan salari dengan mind dan body yang benar. 
Khairil Anwar; Analisis Konstruk Pengukuran Penghargaan Kendiri (Satu Perbandingan antara Konstruk Barat dan Islam)

Seiring dengan perbahasan ini, adapun tajuk yang diangkat dalam tulisan ini mengenai mental-kognitif dan psikososial Islam yang bersumber dari dialektik tentang wilayah studi psikologi psikoanalistik, behavioristik dan humanistic, seperti yang telah diketengahkan di awal pembahasan justifikasi permaslahan. Mencoba mengajukan konsep mental-kognitif dan psikososial Islam adalah sebagai jawaban betapa pentingnya membeicarakan tentang kesadaran (baca ;ruh) dan persekitran.

Cara berfikir Islam adalah suatu konsep yang merujuk pada sudut pandang tiga dimensi kehidupan iaitu pertama: aspek-aspek pembelajaran dari penelusuran peristiwa masa lalu, kedua: memahami konteks sosiotekhnologi temporary dan ketiga: mempersiapkan dan memprediksi keadaan yang akan terjadi di masa hadapan. Ketiga sudut pandang ini bersumber dari pemahaman yang benar dari perspektif Islam yang melintasi aspek-aspek dunia yang profane dan konsekuensi eskatologis di alam akhirat nanti.

Cara befikir Islam sangat bertentangan dengan tradisi dikotomis barat yang sekuler. Barat membezakan antara wahyu dan akal, antara agama dan negara serta antara kebenaran sains dan kebenaran kitab suci agama. Islam dengan landasan al Qur'an dan al Hadis, mengajarkan hidup yang seimbang dan harmonis di antara yang dipertentangkan dalam tradisi barat. Dalam wahyu yang di turunkan kepada Muhammad Allah meletakkan peranan akal pada tempat yang mulia untuk berfikir dan meletakkan wahyu sebagai pedoman berfikir yang benar. Mendapatkan keuntungan duniawi secara materialistic sangat dianjurkan Islam kerana ia termasuk salah satu proses untuk mengolah alam yang telah dianugerhakan Allah untuk kesejahtraan individu dan masyarakat dengan konsep keadilan. Islam menganjurakan membuat tatanan dan pranata social secara hirarkis dalam bentuk sebuah kekuasaan politik dengan tujuan untuk mengatur dan menjamin hak-hak dan kewajiban masrakat secara adil dan bijaksana.Islam memandang semua kegiatan di atas hanyalah proses kehidupan untuk memenuhi keperluan di dunia sebagai makhluk biososial, namun lebih jauh dari itu, proses proses di atas adalah untuk menciptakan kebaikan di muka bumi yang didasari keikhlasan kepada Allah swt.

Dalam banyak literature sering menyamakan makna antara mental dan kognitif. Kedua konsep selalu dmaknakan dengan erti berfikir. Penyamaan makna kedua konsep ini tidak juga begitu disalahkan, kerana memang keduanya merujuk kepada proses berfikir manusia. Lebih jauh apabila kedua konsep ini ditelusuri dengan secara mendalam, maka didapati titik perbezaan untuk menerangkan proses berfikir manusia.

Kognitif secara umum adalah suatu proses yang lebih mengarah kepada proses penemuan suatu maklumat atau pengenalan kembali suatu maklumat. Dalam erti lain kognitif adalah suatu proses kemampuan berfikir manusia untuk mengenali dan menenmukan maklumat sama ada yang bersumber dari dalaman manusia mahupun yang bersumber dari luaran manusia atau factor persekitaran. Manakala mental adalah motor penggerak dan abstraksi dari proses kognitif yang menghubungkan pola-pola 
berfikir dengan alam kesadaran manusia, di mana manusia sedar bahawa sedang terjadinya proses berfikir yang pada akhirnya kegiatan mental inilah yang akan menjadi titik sentral dalam penyelesaian masalah. Jadi dapat dikatakan mental kognitif adalah proses kecerdasan seseorang menangani masalah dari input-input luaran dan dalaman manusia.

Sebagai perbandingan dapat ditela'ah dari teori Cattel (1963) dalam teorinya mengenai organisasi mental, beliau mengklasifikasi kemampuan mental menjadi dua macam, iaitu intelegensi fluid yang merupakan factor bawaan biologis dan intelegensi crystallized yang mereflaksikan adanya pengaruh pengalaman, pendidikan, budaya dan kebiasaan dalam diri seseorang individu.

Dari teori Cattel ini berkemungkinan dapat dianalogikan proses mental kognitif adalah berlansung dari dua jenis kemampuan mental di atas. Ertinya secara semula (fluid) jadi setiap orang telah membawa potensi mental kognitif untuk memproses cara berfikirnya, manakala kualiti mental kognitif bergantung kepada persekitaran (crystallized). Berpunca dari mental kognitif yang tercerahkan atau tidak tercerahkanlah seseorang individu dapat memahami dan menyelesaikan maslah dengan baik. Seiring dengan ini, Prof. Mohammad Saleh (2007) menggambarkan bahawa kemampuan kognitif seseorang yang mengamalakan tahajjud dengan ikhlas, sangat berpengaruh kepada pola coping seseorang individu terhadap seseuatu maslah.
Dengan demikian menurut Saifuddin Azwar (1996) intelegensi crystallized dapat dipandang sebagai endapan pengalaman yang terjadi sewaktu intelegensi fluid bercampur dengan apa yang disebut intelegensi budaya. Intellegensi crystallized akan meningkatkan kadarnya dalam diri seseorang seiring dengan bertambahnya pengalaman. Dengan kata lain, tugas tugas kognitif sebagai keterampilan-ketrampilan dan kebiasankebiasaan telah mengkristal akibat pengalaman sebelumnya, seperti banyaknya menguasai kosa kata, pengetahuan, kebiasaan penalaran dan berbagai hal yang berhubung dengan itu, semua akan meningkatkan intelegensi dimaksud.

Pemahaman mental kognitif dalam perspektif teori Cattel di atas, membawa sebuah implikasi yang positif terhadap mengkristalnya mental kognitif dalam menyelesaikan masalah, disamping memberi pengaruh besar terhadap pengetahuan dan pengalaman keagamaan.

Sesuai dengan permasalahan pokok tulisan ini menyangkut pengkuran mental kognitif Islam, merupakan suatu usaha untuk menyelidiki pengaruh keagamaan, khusunya pengaruh keagamaan Islam terhadap mental kognitif seseorang individu. Adapun peristilahan Mental kognitif Islam adalah suatu batasan masalah yang mengkaji pola-pola dan cara berfikir seseorang individu tentang kualiti pengetahuan, pemahaman dan pengamalan tentang keislaman, atau kalaupun tidak berlebihan dapat juga dikatakan mental kognitif Islam adalah cara berfikir umat Islam dalam memandang diri dan persekitarannya. 
Khairil Anwar; Analisis Konstruk Pengukuran Penghargaan Kendiri (Satu Perbandingan antara Konstruk Barat dan Islam)

Dimungkinkan juga dalam pengkajian mental kognitif Islam adalah dasar berfikir yang utama dan pertama seseorang individu Islam yang dipengaruhi dan yang akan mempengaruhi kualiti hidup seseorang muslim. Sesuai dengan dengan apa yang di ketengahkan oleh Abu Haitam fitrah bererti bahawa manusia yang dilahirkan dengan memiliki kebaikan atau ketidakbaikan (prosperous or unprosperous) yang berhubungan dengan jiwa. la mendasarkannya pada hadits yang cukup populer, "setiap orang dilahirkan dalam keadaan fitrah. Maka orangtuanya yang akan menjadikannya sebagai Yahudi, Nasrani atau Majusi".

Di saping itu Quraish Shihab mengertikan fitrah sebagai unsur, sistem dan tata kerja yang diciptakan Allah pada makhluk sejak awal kejadiannya sehingga menjadi bawaannya. Sejak asal kejadiannya manusia telah membawa potensi keberagamaan yang benar yang diertikan para ulama dengan tauhid. Ini bisa dibaca pada QS Arrum:30 yang ertinya: Maka hadapkanlah wajahmu dengan lurus kepada agama (yang benar). Fitrah Allah yang telah menciptakan manusia atasnya (fitrah itu). Tidak ada perubahan pada fitrah Allah, itulah agama yang lurus, tetapi kebanyakan manusia tidak mengetahui.

\section{Definisi Konsep}

Adapun definisi penghargaan kendiri dalam konteks psikologi menurut Coopersmith (1967) mendefinisikan penghargaan kendiri sebagai penilai peribadi yang ditunjukkan melalui sikap yang dipegang oleh individu tentang dirinya. Penilaian yang dipegang oleh seseorang individu pada kebiasaannya akan kekal pada dirinya. la adalah suatu yang dialami secara subjektif yang diluahkan kepada orang lain melalui pertuturan dan tingkah laku. la menunjukkan sikap seseorang individu sama ada ia merasakan dirinya penting, berkemampuan, berjaya, berguna atau berharga. Menurut Fromm (1956) pula, penghargaan kendiri merujuk kepada kebolehan seseorang individu untuk menyayangi dirinya sendiri dengan menerima kenyataan yang sebenarnya ada pada dirinya.

Manakala Psiko-sosial Islam adalah membawa maksud kekuatan dalaman seseorang yang berinterkaksi dengan dunia sosialnya ataupun kekuatan jiwa keislaman seseorang individu untuk berhubungan dengan masyarakat sekitarnya. Kekuatan psikososial memebri sudut pandang komunal yang lebih berempati di tengah masyarakat. Namun sifat empati ini semata-mata atas dorongan rahmatan lil alamiin. Rendahnya psikososial adalah juga berpunca dari melemahnya mental-kognitif Islam seseorang.. Manakala konsep psikososial Islam dioperasionalkan dengan domaindomain sebagai berikut : Pertama: Instrinsik Islam : mengenali konsep khalifah, mengenali konsep keunggulan diri, mengenali misi, membangun misi, menciptakan wawasan, komitmen, jati diri, kecerdasan, cita-cita, keberuntungan, kreativiti, obsesi dan ibadah. Kedua : Sikap Dan Cara Berfikir : Prasangka, saling percaya, saling mendukung, koperatif, terbuka, performa terbaik, defensif, tertutup, menahan informasi (terdiri dari: nonkooperatif dan performa turun), prinsipprinsip hidup (terdiri dari: spiritual kapital 
dan material kapital), pengalaman (terdiri dari: positif dan negatif), kepentingan (terdiri dari: jangka panjang dan jangka pendek), sudut pandang (wisdom) based on Allah swt dan Rasul, pembanding (standard nilai tinggi, standard nilai rendah, objektif dan subjektif), dan literature (terdiri dari : agama, falsafah dan IImu). Ketiga : Dakwah Dan Nilai Diri : Iman dan yakin yang betul, istikhlas, insan (tawajuh), ihtisab, ikhlas (redha), mujahadah nafsi, yakin pada kalimat thoyyibah, solat khusyu', ilmu ma'a zikir, ikromul muslimin, tashihunniyat dan dakwah wat tabligh. Keempat : Pandangan Kehidupan Sosial : Moral dalam pandangan Islam, perbaikan moral dalam Islam, reformasi moral, pembetulan dan perbaikan sosial, ikatan sosial dan moral, hubungan keluarga, tetangga dan sahabat, saling tolong dan membantu, hubungan sesama muslim, perbaikan individu dan keluarga, perbaikan keluarga, ilmu pengetahuan, umat Islam dan era ilmu pengetahuan dan mencerdaskan masyarakat.

\section{Metod Kajian}

Kajian ini mengambil dua pendekatan iaitu pertama kajian lapangan kerana ia melibatkan dua alat pengukuran antaranya alat pengukuran penghargaan kendiri dan alat pengukuran psiko-sosial Islam. Kedua kajian kualitatif dalam bentuk konten analitis yang mengkaji secara mendalam konstruk dari dua alat pengukuran yang digunakan. Kajian ini Telah mengambil responden seramai 490 orang dari latar belakang demografi yang berbeza. Lokasi kajian ini diambil dari empat negeri iaitu Terengganu, Kelantan, Melaka Dan Perak. Pemilihan lokasi ini berdasarkan keperluan untuk mengambil responden lelaki dan perempuan. Maka Responden perempuan diambil pada pusat pemulihan terengganu dan kelantan, manakala responden lelaki diambil pada pusat pemulihan Perak dan Melaka. Data dalam penyelidikan dianalisis dengan ujian statistik regresi dan dapatan kajian akan dibahas dengan pendekatan konten analisis.

\section{Dapatan Kajian}

Adapun dapatan kajian adalah sebagai berikut :

Jadual 1. Pengaruh Psikososial Islam terhadap penghargaan kendiri

\begin{tabular}{|c|c|c|c|c|}
\hline & \multicolumn{2}{|c|}{ Penghargaan kendiri } & \multirow[t]{2}{*}{$\mathrm{t}$} & \multirow[t]{2}{*}{$p$} \\
\hline & $B$ & Beta & & \\
\hline Psikososial Islam & -.004 & -.052 & -1.109 & .268 \\
\hline
\end{tabular}

Dari jadual 1 di atas menunjukkan psikososial Islam tidak memberi pengaruh terhadap tahap penghargaan kendiri di kalangan responden penelitian. Walupun tidak signifikan, arah beta yang ditunjukkan adalah bernilai negatif, yang menunjukkan kecendrungan adanya percanggahan antara kedua pengukuran di atas. 
Khairil Anwar; Analisis Konstruk Pengukuran Penghargaan Kendiri (Satu Perbandingan antara Konstruk Barat dan Islam)

Jadual 2. Perbandingan Min Psikososial Islam dan Min Penghargaan kendiri mengikut jenis kesalahan.

\begin{tabular}{|l|c|c|c|}
\hline \multicolumn{1}{|c|}{ Jenis Kesalahan } & $\mathrm{N}$ & Min Psikososial Islam & $\begin{array}{c}\text { Min Penghargaan } \\
\text { kendiri }\end{array}$ \\
\hline seksual & 36 & 317.03 & 26.83 \\
\hline gangterisme & 42 & 318.88 & 26.82 \\
\hline mencuri & 115 & 320.14 & 26.43 \\
\hline dadah & 136 & 330.30 & 26.41 \\
\hline remaja luar kawalan & 74 & 333.81 & 26.38 \\
\hline lari dari rumah & 40 & 340.52 & 25.96 \\
\hline
\end{tabular}

Walaupun secara ujian inferensi tidak terdapat perbezaan min tahap psikososial Islam dan penghargaan kendiri yang signifikan mengikut jenis kesalahan, namun jadual di atas secara deskriptif menunjukkan suatu arah min yang bercanggah antara dua pengukuran di atas. Jadual dia atas menggambarkan semakin tinggi tahap kesalahan seseorang memperlihatkan min penghargaan kendiri yang semakin tinggi dan sebaliknya semakin tinggi tahap kesalahan seseorang semakin menunjukkan tahap psikososisl yang rendah.

\section{Perbincangan}

\section{Pandangan Umum Aliran Psikologi Barat}

Berikut secara kritikal dapat difahami bahawa, pandangan psikoanalitik yang diasaskan oleh Sigmund Freud, tingkahlaku adalah disebabkan oleh naluri individu. Naluri hidup (biofilus) dan mati (necrofilus) serta personaliti individu didorong oleh id, ego, dan superego. Psikoanalisis sering disebut juga sebagai psikoseksual. Ertinya dorongan hidup manusia adalah berawal dari libido seksual manusia. Dalam bahasa Freud, seksual disini adalah kuasa dasar sebagai pendorong setiap tingkahlaku manusia. Beliau menterjemahkan seksual bukan dalam erti yang sempit sebagai bentuk pemuasan kelamin, tetapi lebih merupakan sebagai bentuk pemuasan diri. Pemikiran ini sepertinya ideantik dengan filsafat epicurism yang berasas material-hedonistik, yang bermuara pada pemuasan diri. Walaupu Freud tidak bertujuan untuk dapat menikmati segala sesuatu seperti yang ingin dituju oleh Epicurus, namun Freud berkeyakinan kuat bahawa manusia digerakkan oleh instink seksual yang membuat manusia merasa betah menjalani kehidupan. Keyakinan Freud ini telah melintasi pada batas-batas spiriualitas manusia. Keyakinan kepada Tuhan adalah dorongan pemuasan manusia. Dalam pandangan Freud semuanya adalah semua, yang ada adalah diciptakan ?( Khaidzir $\mathrm{Hj}$. Ismail dan Khairil Anwar, 2009).

Bagi Freud, Tuhan sebenarnya Tidak ada. Tapi ia diciptakan oleh kepuasan-kepuasan tertentu oleh sebab hal-hal yang manusia sangat terbatas untuk memahaminya. Hingga Tuhan itu dihadirkan oleh manusia menurut tahap kefahaman terhadap realiti. Logiknya, 
semakin dekat manusia ke titik positivistik, semakin kecil kemungkinan ia memerlukan Tuhan. Positivistik Freud sedikit berbeza dengan positivitik Comte. Comte mengatakan Positivistik adalah tahap yang nil Tuhan, sementara Freud tetap berkeyakinan Tuhan diperlukan oleh manusia sebagai pemuas hidupnya, tapi dalam intensitas yang sangat kecil sekali. Freud adalah seorang spiritual-ateistik, yang bermain dalam ranah psikolgi moderen. Yang menjadi pertanyaan apakah manusia tidak memiliki kreasi kemanusiaan yang filantrofis dan altruistik. Dua aspek ini bahkan dalam banyak hal berbanding terbalik dengan pemuasan diri. Filantropis dan altruistik dalam banyak hal, manusia harus menahan pemuasan dirinya untuk pemuasan sistem. Dalam bahasa profetikspiritulism telah banyak darah manusia dikorbankan oleh perjuangan sistem. Dalam bahasa agama-agama, heroisme kemanusiaan puncaknya ditandai dengan menumpakan darah kehidupan menuju kematian yang mulia oleh sebuah pemuasan sistem. ?( Khaidzir Hj. Ismail dan Khairil Anwar, 2009).

Behaviorisme berkeyakinan kuat bahawa sumber dari tingkahlaku manusia adalah ditentukan oleh suatu pembiasaan dan pelaziman. Dalam erti lain bahawa manusia dengan kekompleksitasannya dapat dibentuk dengan pola-pola pembelajaran tertentu dan tingkahlakunya dapat dieksperimen sebagai pembuktian terhadap berhasilnya kaedah tertentu mempengaruhi tingkahlaku manusia. Skinner dan Pavlo sangat terdepan dalam hal ini. Mereka telah menganalogikan tingkahlaku manusia dari hasil-hasil eksperimen terhadap haiwan. Skinner terkenal dengan eksperimen tikus yang mampu menekan tuas sebuah kotak makanan dan Pavlo dengan eksperimen air liur anjing yang merespon bunyi loceng yang dikondisikan sebagai tanda makanan disediakan. Eksperimeneksperimen ini mendapat hadiah nobel sebagai penemuan terbesar dalam memahami tingkahlaku manusia. Penemuan-penemuan behavioristik di atas telah dikembangkan dengan sangat pesat hingga dijadikan sebagai dasar metodologi peningkatan dalam metod pedagogi manusia (baca; psikologi pendidikan). Yang menjadi pertanyaan, sejauh mana peranan pembiasaan dan eksperimentasi terhadap pembiasaan ini menerangkan sebuah iluminasi kesedaran kecerdasan manusia yang merdeka? (? (Khaidzir $\mathrm{Hj}$. Ismail dan Khairil Anwar, 2009).

Manakala humanisme yang mencuba mensintesis dua aliran di atas melalui potensi manusia untuk melakukan pemilihan-pemilihan yang logik yang sesuai dengan potensi kemanusiaannya. Pemikiran humanisme dalam psikologi, disamping sebagai resultansi dari hasil dialektik dalam paradigma psikologi, juga hasil dari implikasi filsafat humanisme barat, yang didorong oleh semangat renaisance Eropah. Dalam konteks psikologi, humanisme berkeyakinan pada self-centre. Diri (individu) adalah menentukan sistem. Syarat utama diri yang dapat menentukan sistem menjadi baik adalah diri yang telah dipenuhi keperluan-keperluan tertentu. Pantulan psikologi humanisme, Abraham Maslow, berteori bahawa manusia memiliki peringkat-peringkat keperluan yang harus dipenuhi secara liner. Peringkat keperluan manusia yang paling dasar yang harus dipenuhi adalah keperluan pakaian, makanan (basic need). 
Khairil Anwar; Analisis Konstruk Pengukuran Penghargaan Kendiri (Satu Perbandingan antara Konstruk Barat dan Islam)

Sementara peringkat keperluan manusia yang tertinggi adalah aktualisasi diri (self ectulisation). Keperluan aktualisasi diri tidak akan pernah tercapai apabila keperluan dasar tidak dipenuhi.

Teori Maslow, banyak di anut dalam bidang pengurusan organisasi sebagai dasar untuk meningkatkan prestasi pekerja untuk mencapai produk tertentu. Maslow berkeyakinan bahawa sebesar apapun potensi kecerdasan manusia untuk sampai pada tahap aktualisasi diri, namun apabila pada tataran basic need-nya tidak dipenuhi, maka adalah suatu kegagalan yang fatal untuk membicarakan potensi manusia. Yang menjadi pertanyaan, mungkinkah manusia cerdas akan dikalahkan perjuangannya untuk sistem oleh ketidaktersediaan basic need? Sementara dalam banyak hal apakah tidak mungkin basic need harus disediakan oleh kecerdasan?( Khaidzir $\mathrm{Hj}$. Ismail dan Khairil Anwar, 2009).

\section{Analisis konstruk alat pengukuran Penghargaan Kendiri}

Percanggahan dapatan kajian antara pengukuran penghargaan kendiri dengan psikososial Islam adalah menggambarkan percanggahan yang disebabkan oleh terdapatnya perbezaan yang mendasar dari konstruk terbentuknya dua pengukuran dimaksud. Salah satu contoh item penghargaan kendiri menyebutkan " saya merasa mempunyai ciri kualiti yang baik" secara sepintas item ini seakan akan memperlihatkan keyakinan diri seseorang yang akan menjana terhadap penghargaan kendirinya, namun lebih jauh apabila ditilik dengan pendekatan konstruk Islam, maka item ini bercanggah dengan prinsip ketauhidan sebagai muara penghambaan seseorang pada Allah SWT. Islam sangat menggalakkan bahkan hampir mewajibkan untuk seseorang mencapai kualiti yang baik , namun Islam sangat melarang seseorang untuk merasa berkualiti. Ataupun Islam mewajibkan untuk mencapai kebenaran namun disisi lain Islam bahkan melarang seseorang merasa benar. Dalam konsep Islam merasa paling baik adalah disebut dengan peristilahan "ujub" sebagai suatu dosa dalaman seseorang melihat diri paling baik. Dalam Islam konsep penghargaan kendiri bukanlah untuk merasa diri lebih baik, namun penghargaan kendiri Islam adalah bermaksud seseorang itu tidak akan terkesan oleh kemiskinan kekayaan dan tidak putus dari rahmat Allah ia memiliki penghargaan kendiri bahawa dirinya adalah wajib dipelihara kerana Allah telah mengamanahkan kepadanya

Secara analitis alat pengukuran self esteem ini selari dengan teori Maslow, yang menghubungkan antara pencapaian materil-fizikal dengan penghargaan diri seseorang. Selain itu penghargaan kendiri juga sangat berhubungan dengan status sosial ekonomi (SES) seperti tahap pendidikan, pendapatan dan pekerjaan seseorang. Artinya semakin baik tahap SES seseorang maka akan semakin tinggi tahap penghargaan kendiri seseorang. Dalam konstruk Islam SES bukanlah menjadi faktor utama untuk seseorang memiliki penghargaaan kendiri diri. Apa bila seseorang penghargaan kendirinya semakin baik apa bila meiliki tahap SES yang tinggi, maka orang inilah yang paling rendah penghargaan dirinya dalam Islam, 
kerana ia telah mengukur dirinya dengan benda-benda fizik material sehingga rumah indah dan mobil mewah yang dia miliki akan menjadi "meke up" untuk menampilkan dirinya. Dalam Islam konsep penghargaan kendiri bukanlah untuk merasa diri lebih baik, namun penghargaan kendiri Islam adalah bermaksud seseorang itu memiliki hakhak bersosial ditengah masyarakat. Walaupun ia seorang yang miskin ia tidak akan takut untuk menyampaikan yang haq kepada yang lebih kaya dan berpangkat tinggi, kerana menyampaikan yang haq adalah perintah Allah, maka ia mempunyai penghargaan kendiri untuk melaksanakan tugas-tugas yang telah diperintahkan Allah. la merasa yakin bahwa Allah sangat menyukai orang orang yang berani menyuarakan kebenaran. Penghargaan kendiri Islam membawa maksud tidak akan terkesan oleh kemiskinan dan kekayaan dirinya atau orang lain dan ia tidak akan berputus asa dari rahmat Allah SWT. ia memiliki penghargaan kendiri bahawa dirinya adalah manusia pilihan untuk melaksanakan seluruh amanah yang datang dari Allah SWT. Apa yang dimaksudkan oleh Maslow tentang aktualisasi diri baru akan tercapai dengan terpenuhinya keperluan fizikal dan pengahrgaan dari individu ataupun sosial terhadap dirinya adalah suatu konsep yang bercanggah dalam realiti seseorang mukmin yang sejati. Mukmin sejati seperti para sahabat nabi, yang dalam sejarah digambarkan memakan rendaman daun dan ranting kayu yang kering namun tidak membuat mereka surut untuk melaksanakan peranan sosial mereka yang tertinggi iaitu syahid untuk menegakkan kebenaran.
Tahap Jenayah Dan Penghargaan Kendiri

Dalam banyak dapat kajian menunjukkan semakin tinggi kejahatan seseorang sering dijumpai adalah individu yang memiliki penghargaan kendiri yang cukup tinggi. Seperti wanita-wanita yang melacurkan diri memiliki penghargaan kendiri yang tinggi (Bandingkan, Sarlito Wirawan Sarwono, 2006). Hal ini terjadi tidak terlepas dari konstruk dasar penghargaan kendiri yang lebih mengarah kepada dalam konteks fizikal. Boleh jadi pelacur merasa dirinya memiliki kelebihan fisik maka memiliki dorongan yang positif untuk melakukan perbuatan yang dilarang tersebut.

\section{Kesimpulan Dan Saranan}

Dengan demikian alat pengukuran penghargaan kendiri ini tidak dapat digunakan sebagai instrumen untuk menetapkan bencmark penghargaan kendiri masyarakat Islam, khususnya remaja Islam. Dalam Budaya barat seseorang mencapai kejayaan adalah untuk sebuah digniti tertentu namun dalam Islam semata-mata hanya untuk mengabdi dan mencari redha Allah. dalam konsep barat kemiskinan adalah dianggap sebagai musuh untuk menjatuhkan penghargaan kendidir seseorang namun di dalam Islam kemiskinan adalah sebuah sistem keseimbangan hidup. Yang paling berbahaya di dalam. Islam adalah orang yang merasa kaya atau orang merasa miskin. Sebab orang yang merasa kaya dan merasa miskin inilah pemicu penyakit masyarakat yang sebenarnya. 
Khairil Anwar; Analisis Konstruk Pengukuran Penghargaan Kendiri (Satu Perbandingan antara Konstruk Barat dan Islam)

Seyugianya alat pengukuran atau berbagai bentuk modul yang berasaskan penghargaan kendiri barat dimaksud, dapat dipertimbangkan kembali penggunaannnya dalam program kecemerlangan dan kesejahteraan psikologi masyarakat muslim, khususnya remaja muslim sebagai pemangkin negara untuk masa hadapan.

\section{Bibliografi}

Hashimi-al, Abdul Hamid. 1989. Proses pengislaman psikologi, Sains sosial dan Sains Tulen, Kuala Lumpur, Dewan Bahasa dan Pustaka

Khaidzir $\mathrm{Hj}$. Ismail dan Khairil anwar. (2009). Pengukuran variable psikologi Islam: Pembinaan mental-kognitif Islam, Psikologi Islam : Falsafah, Teori dan Aplikasi, Kuala Lumpur: Institut Islam Hadhari \& IBook Publication.

Mostafa Kamal Mokhtar. 2003. pembangunan Rohani Menurut Perspektif Tasawuf Dan Psikologimoden Jurnal Islamiyyat $24: 21$ - 35

Sarlito Wirawan Sarwono. (2006) Psikologi remaja, Jakarta: PT.Raja Grafindo Persada: Jakarta.

Wan Mohd. Nor Wan Daud. (1991). Penjelasan budaya ilmu. Kuala Lumpur: Dewan Bahasa dan Pustaka.
Ajzen, Icek. (2005). Attitudes, personality and behavior, England: Open Unversiti Press.

Al Attas, Syed Muhammad Naquib. (1995). Prolegomena to the metaphysics of Islam, an exposition of the fundamental elements of the worldview of Islam. Kuala Lumpur: ISTAC.

Al Faruqi, Ismail Ragi. (1991). Pengislaman ilmu, (Terj.). Kuala Lumpur: Dewan Bahasa dan Pustaka.

Aldwin, C. M. 1994. Stress, coping and development: an integrative perspective. New York: Guilford Press.

Badri, Malik. (1980). Dilema ahli psikologi Islam : keadaan serba salah yang dihadapi oleh pakar ilmu jiwa Islam (dialihbahasa dan disunting oleh Fadlullah Wilmot), Petaling Jaya: FAWI.

Baharudin Ahmad. (2008). Falsafah sains dari perspektif Islam, Kuala Lumpur: Dewan Bahasa dan Pustaka.

Hawari, D. 1997. Al-Quran: Ilmu Kedokteran Jiwa dan Kesehatan Jiwa. Yogyakarta: PT Dana Bhakti Prima Yasa

Hidajat Nataatmajaya. (1983). membangun ilmu pengetahuan berlandaskan Ideologi (al bayyinah). Bandung: Iqra'.

Khaidzir $\mathrm{Hj}$. Ismail dan Khairil anwar. (2009). Pengukuran variable psikologi Islam: Pembinaan mental-kognitif Islam, Psikologi 
AL-Fikra: Jurnal Ilmiah Keislaman, Vol. 15, No. 1 , Januari - Juni 2016

Islam : Falsafah, Teori dan Aplikasi, Kuala Lumpur: Institut Islam Hadhari \& IBook Publication.

Khaidzir Hj. Ismail et al (Ed.). (2009). Psikologi Islam : Falsafah, Teori dan Aplikasi, Kuala Lumpur: Institut Islam Hadhari \& IBook Publication.

Khairil Anwar dan Khaidzir Hj. Ismail. (2009). Profil Mental-Kognitif Dan Psiko-Sosial Islam Di Kalangan Remaja Beresiko, prosiding International Seminar of Islamic though,Bangi: UKM

Osman Bakar. (1998). Classificationn of knowledge in Islam. Cambridge: The Islamic Texs Society.

Wan Mohd. Nor Wan Daud. (1998). The concept of knowledge in Islam and its implications for education in developing country, London: Mansell Publishing Limited.

Sardar, Ziauddin. (2000). Merombak pola fakir intelektual muslim, Yogyakarta: Pustaka Pelajar. 